\title{
A variant of estrogen receptor- $\alpha$, ER- $\alpha 36$ is expressed in human gastric cancer and is highly correlated with lymph node metastasis
}

\author{
HAO DENG ${ }^{1}$, XUAN HUANG $^{1}$, JUN FAN $^{1}$, LIUBAI WANG $^{1}$, QIN XIA $^{1}$, \\ XIUPING YANG ${ }^{2}$, ZHAOYI WANG ${ }^{3}$ and LIJIANG LIU ${ }^{1,4}$ \\ ${ }^{1}$ Department of Pathology and Pathophysiology, School of Medicine, Jianghan University, Wuhan, Hubei Province \\ 430056; ${ }^{2}$ Department of Pathology, Xiehe Hospital, Tongji Medical College, HuaZhong University of Science \\ and Technology, Wuhan, Hubei Province 430030, P.R. China; ${ }^{3}$ Departments of Medical Microbiology and \\ Immunology and Pathology, Creighton University Medical School, 2500 California Plaza, Omaha, NE 68178, \\ USA; ${ }^{4}$ Jiangda Pathology Center, Jianghan University, Wuhan, Hubei Province 430056, P.R. China
}

Received December 31, 2009; Accepted March 9, 2010

DOI: 10.3892/or_00000842

\begin{abstract}
Gastric cancer is one of the most common cancers in the world; almost two-thirds of gastric cancer cases and deaths occur in less developed regions. The molecular and cellular events during development of gastric cancer remain unclear. Herein, we examined the expression of ER- $\alpha 36$, an ER- $\alpha$ variant, in established gastric cancer cell lines and specimens from 22 gastric cancer patients. RT-PCR, Western blot and immunohistochemistry methods were used to assess expression levels of ER- $\alpha 36$. ER- $\alpha 36$ localization in gastric cancer cells was determined with an immunofluorenscence assay. Both mRNA and protein of ER- $\alpha 36$ were detected in all established gastric cancer cell lines examined. Higher levels of ER- $\alpha 36$ mRNA were expressed in 17 of 22 (77.27\%) tumor specimens examined compared to the paired normal tissues $(\mathrm{p}<0.05)$. ER- $\alpha 36$ protein was expressed mainly on the plasma membrane and in the cytoplasm of the established gastric cancer cells. ER- $\alpha 36$ expression is highly correlated with lymph node metastasis in human gastric cancer $(\mathrm{P}<0.05)$. The estrogen receptor variant ER- $\alpha 36$ is highly expressed in human gastric cancer. ER- $\alpha 36$ expression may be used as a predictive marker for lymph node metastasis of gastric cancer.
\end{abstract}

\section{Introduction}

Estrogen signaling is pivotal in the establishment and maintenance of reproductive function in men and women. It is

Correspondence to: Dr LiJiang Liu, Jiangda Pathology Center, Jianghan University, Wuhan, Hubei Province 430056, P.R. China E-mail: liulijiang@163.com

Key words: gastric cancer, ER- $\alpha 36$, lymph node metastasis also involved in normal development and physiology of bone, cardiovascular and neuronal systems. It is believed that dysregulated estrogen signaling is involved in the initiation and development of neoplasia in at least breast and endometrial cancers (1). However, the involvement of estrogen signaling in other types of human cancer has not been well established.

The diverse physiological functions of estrogens are mediated by specific nuclear receptors designated as estrogen receptors (ERs). In 1986, the cloning of the estrogen receptor (ER) was first reported (2,3). Until 1996, it was assumed that there was only one ER responsible for all of the physiological and pharmacological effects of natural and synthetic estrogens and antiestrogens. However, in 1996, a second ER was cloned (4). Currently, the first ER discovered is referred to as ER- $\alpha$, while the second is called ER- $\beta$.

ER- $\alpha$ and ER- $\beta$ share a common structural architecture $(5,6)$. Both are composed of three independent but interacting functional domains: the N-terminal $\mathrm{A} / \mathrm{B}$ domain, the $\mathrm{C}$ or DNA-binding domain, and the $\mathrm{D} / \mathrm{E} / \mathrm{F}$ or ligand-binding domain. The N-terminal domain of ER- $\alpha$ encodes a ligandindependent activation function (AF-1), a region involved in interaction with co-activators, and transcriptional activation of target-genes. The DNA-binding domain or C domain contains a two zinc-finger structure, which plays an important role in receptor dimerization and binding to specific DNA sequences. The $\mathrm{C}$-terminal $\mathrm{E} / \mathrm{F}$ domain is a ligand-binding domain that mediates ligand binding, receptor dimerization, nuclear translocation, and a ligand-dependent transactivation function (AF-2).

It has been well documented that the ERs are ligandactivated transcription factors that stimulate target gene transcription (1). Stimulation of target gene expression by ERs in response to estrogens is prevailingly thought to be responsible for cell proliferation. Despite the clarity with which ERs have been shown to act as transcription factors, it became apparent that not all of the physiological effects mediated by estrogens are accomplished through a direct 
effect on gene transcription. Another signaling pathway (also known as a 'non-classic', 'non-genomic' or 'membrane signaling' pathway) exists that involves cytoplasmic proteins, growth factors and other membrane-initiated signaling pathways (7).

Previously, we identified and cloned a novel variant of ER- $\alpha$, ER- $\alpha 36$, with a molecular weight of $36 \mathrm{kDa}(8,9)$. ER- $\alpha 36$ lacks both transactivation domains AF-1 and AF-2 of the 66-kDa full-length ER- $\alpha$ (ER- $\alpha 66)(8,9)$. The transcripts of ER- $\alpha 36$ are initiated from a previously unidentified promoter located in the first intron of the ER-a66 gene (8). Further research found that ER- $\alpha 36$ is subjected to a transcriptional regulation totally different from the ER- $\alpha 66$ (10).

Estrogens have been proposed to provide protection against gastric cancer of women before menopause (11); the incidence of gastric cancer is higher in men than in women before menopause (12). The incidence of gastric cancer in women after menopause reaches a level similar to men (13). These findings suggested an involvement of estrogen signaling in protection against human gastric cancer. Tokunaga et al (14) first reported ER- $\alpha 66$ expression in human gastric cancer. Since then, a number of laboratories have reported expression of ER- $\alpha$ in gastric cancer and correlated ER status to tumor grade $(15,16)$. In addition, the effects of estrogens on the growth of human gastric cancer xenografts in nude mice were studied (17). It was found that ER- $\alpha 66$ was expressed mainly in the cytoplasm of gastric carcinoma cells while it is predominantly expressed in the cell nuclear of breast cancer cells (18).

In the present study, we examined the expression and localization of ER- $\alpha 36$ in established gastric cancer cells and specimens from gastric cancer patients. We also examined correlations between ER- $\alpha 36$ expression and lymph node metastasis of human gastric adenocarcinoma.

\section{Materials and methods}

Cell culture. Human gastric adenocarcinoma cell lines BGC823 and SGC7901 were obtained from Cell Center of Basic Medicine, Chinese Academy of Medical Sciences (Beijing, China). Human gastric cancer cell line AGS and breast cancer cell line MCF-7 were obtained from American Type Culture Collection (ATCC, Manassas, VA, USA). Human gastric cancer cell line MKN-45 was kindly provided by the laboratory of Molecular and Immunopharmacology of Tongji Medical College. All cells were maintained in RPMI-1640 medium plus $10 \% \mathrm{FCS}$ at $37^{\circ} \mathrm{C}$ in a $5 \% \mathrm{CO}_{2}$ atmosphere.

Gastric tumor samples. Tumor tissues, corresponding normal gastric tissues and tumor-adjacent tissues of 22 gastric cancer patients (between January and July, 2007) were obtained from the Xiehe Hospital of Tongji Medical College, after approval of the Institutional Review Board. Tumor tissues were divided into two groups. One group was fixed in $10 \%$ formalin, embedded in paraffin and stained with hematoxylin and eosin and immunohistochemistry. The other group was snap-frozen in liquid nitrogen and stored at $-80^{\circ} \mathrm{C}$ for RNA extraction. The patients comprised 13 men and eight women aged 36-79 (mean: 56.9 years). Prior to surgery, none of the patients received any anti-cancer treatment. The tumor size, histological differentiation, $\mathrm{T}$ stage and $\mathrm{N}$ stage were evaluated according to the clinicopathological classification of the WHO (2003).

RT-PCR amplification. For RT-PCR analysis, gastric cancer cells and frozen tissues of gastric adenocarcinoma were disrupted in TRIzol reagent (Invitrogen, San Diego, CA, USA) and total RNA was isolated according to the manufacturer's instructions. Total RNA was reversely transcribed into cDNA by RT-PCR kit (Takara, Dalian, China). Following reverse transcription, PCR reaction was carried out with 35 cycles using the following conditions: $94^{\circ} \mathrm{C}$ for $40 \mathrm{sec}, 60^{\circ} \mathrm{C}$ for $1 \mathrm{~min}$ and $72^{\circ} \mathrm{C}$ for $40 \mathrm{sec}$. ER- $\alpha 36$ primers and GAPDH Primers were designed by Primer 5.0 (Primer Biosoft International, Palo Alto, CA, USA) and were used simultaneously in the same reaction. The following primers were used: ER- $\alpha 36$ forward primer 5'-CAAGTGGTTTCCTCGTGTCTAAAG-3'; ER- $\alpha 36$ reverse primer 5'-TGTTGAGTGTTGGTTGCC AGG-3'; GAPDH forward primer 5'-ACCACAGTCCATG CCATCAC-3'; GAPDH reverse primer 5'-TCCACCACCC TGTTGCTGTA-3'. The PCR products (219 bp for ER- $\alpha 36$ and 452 bp for GAPDH) were separated on $1.5 \%$ agarose gel and stained with GoldView (SBS Genetech Co., Beijing, China). The densities of DNA bands were assessed with the analysis software (Biostep Photoimpact, Beijing, China) and the relative values were determined.

Western blot assay. Cells were lysed with the RIPA buffer (Beyotime, Shanghai, China). Proteins concentration was determined with an Enhanced BCA Protein assay kit (Beyotime). Cell lysates were mixed with gel-loading buffer, separated by $12 \%$ SDS-PAGE gels and transferred to a PVDF membrane (Millipore, Billerica, MA, USA). The membrane was probed with the indicated antibodies and visualized with the appropriate secondary antibodies (Beyotime) and enhanced chemiluminescence (ECL) reagents (Beyotime). The densities of protein bands were determined with the Totallab analysis software (Nonlinear Dynamics Technical, NC, USA). The rabbit polyclonal ER- 236 antibody was development as described before (9). The anti- $\beta$-actin (C4) antibody was purchased from Santa Cruz Biotechnology (CA, USA).

Immunofluorescence and immunohistochemistry assays. Gastric cancer cells cultured on cover glass were fixed with acetone for $10 \mathrm{~min}$. After washing with PBS, cells were permeabilized with $0.5 \%(\mathrm{~V} / \mathrm{V})$ Triton $\mathrm{X}-100$ for $10 \mathrm{~min}$, washed with PBS and blocked with $3 \%$ serum in PBS at room temperature for $1 \mathrm{~h}$. The cover glasses were incubated with the rabbit polyclonal ER- $\alpha 36$ antibody at room temperature for $1 \mathrm{~h}$ and washed 3 times with PBS containing $0.5 \%$ Triton X-100 (PBST), then incubated with a Cy3-labeled secondary antibody (Beyotime). The specificity of staining was verified by omitting the primary antibody. Finally, the cover glasses were washed 3 times with PBST, one time with PBS, then mounted with anti-fade medium (Molecular Probes, Eugene, OR, USA) and examined under a Olympus microscope at x400 magnification. Hoechst 33258 was used for nuclear staining.

Immunohistochemical staining was performed on $4-\mu \mathrm{m}$ thick tumor sections via a 'two-step' assay. Briefly, tissue slides were deparaffinized with xylene and rehydrated through 


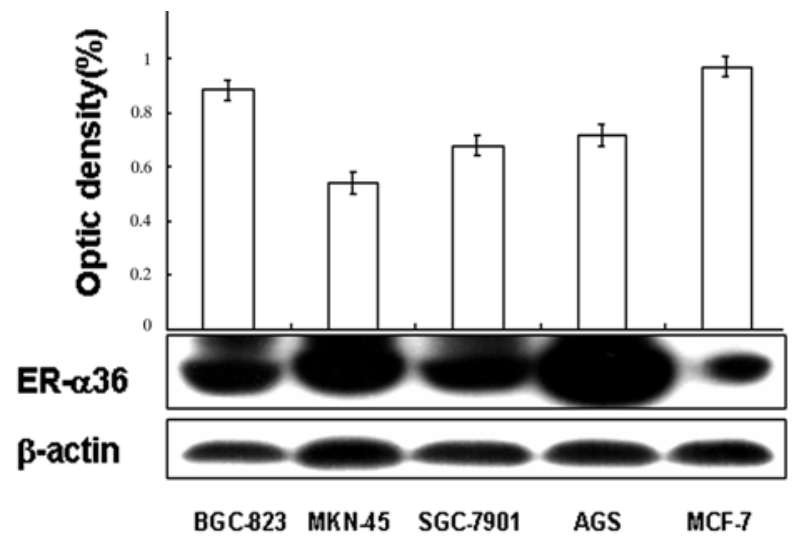

Figure 1. Western blot analysis of ER- $\alpha 36$ protein expression in human gastric cancer cell lines. Expression levels of ER- $\alpha 36$ protein were assessed in four human gastric cancer cell lines, SGC7901, BGC823, MNN45 and AGS. ER-positive breast cancer MCF-7 cell line was used as a positive control. The levels of ER- $\alpha 36$ and $B$-actin protein expression were determined with a video-densitometry system and the band densities relative to the density of $\beta$-actin band are shown.

a gradual alcohol series. The endogenous peroxidase activity was blocked by incubation in a $3 \%$ hydrogen peroxide/ methanol buffer for $10 \mathrm{~min}$. Antigen retrieval was carried out by immersing the slides in EDTA buffer ( $\mathrm{pH}$ 8.0) and boiling in a water-bath at $95^{\circ} \mathrm{C}$ for $25 \mathrm{~min}$. The slides were rinsed in phosphate-buffered saline (PBS) and incubated with normal goat serum to block non-specific staining. The slides were then incubated with the polyclonal anti-ER- $\alpha 36$ antibody at a dilution of 1:50 overnight at $4^{\circ} \mathrm{C}$ in a humidified chamber. The slides were incubated with the second antibody (horseradish peroxidase-conjugated goat anti-rabbit immunoglobin; 1:100, Dako, CA, USA) for $45 \mathrm{~min}$. Diaminobenzidine was used as a chromagen and slides were counterstained with hematoxylin. Scoring for ER- $\alpha 36$ staining was graded as follows: no staining or staining observed in $(10 \%$ of tumor cells was given a score 0 ; faint/barely perceptible staining detected in $\geq 10 \%$ of tumor cells was scored as $1+$; a moderate or strong staining observed in $\geq 10 \%$ of tumor cells was scored as $2+$ or $3+$, respectively. A score of 0 and $1+$ was considered negative whereas $2+$ and $3+$ were considered positive. Immunostained slides were evaluated by two pathologists independently in a blinded manner. In most cases, the evaluations of the two pathologists were identical; any discrepancies were resolved by re-examination and consensus.

Statistical analysis. The correlation between ER-a36 expression and clinic pathologic characteristics was determined using Pearson's $\chi^{2}$ test. $\mathrm{P}<0.05$ was considered statistical significance. The statistical analyses were performed using SPSS 12.0 software.

\section{Results}

ER-a36 is expressed in established gastric cancer cell lines. To determine whether the estrogen receptor variant, ER- $\alpha 36$ is expressed in gastric cancer, we examined ER- $\alpha 36$ expression

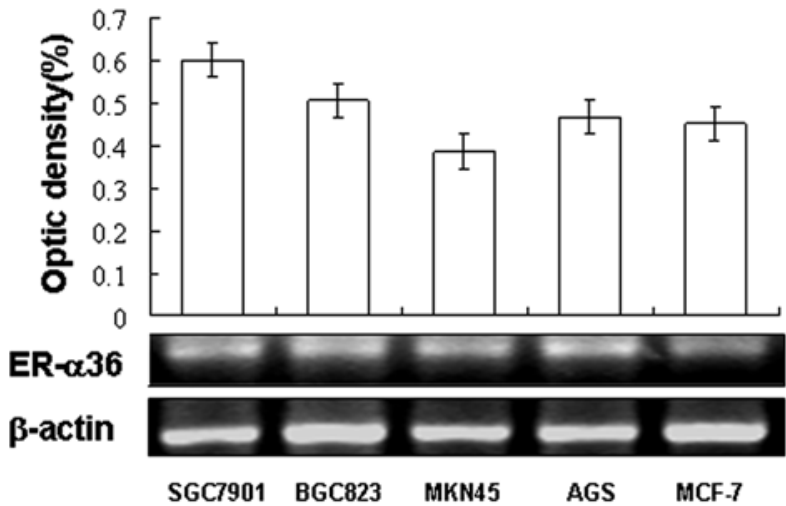

Figure 2. RT-PCR analysis of ER- $\alpha 36$ mRNA expression in human gastric cancer cell lines. Expression levels of ER- $\alpha 36$ mRNA were examined in four human gastric cancer cell lines, SGC7901, BGC823, MNN45 and AGS. ER-positive breast cancer MCF-7 cell line was used as a positive control. The levels of mRNA expression of ER- $\alpha 36$ and $\beta$-actin were determined with a video-densitometry system and the band densities relative to the density of $\beta$-actin band are shown.

in four gastric cancer cell lines including SGC-7901, AGS, BGC-923 and MKN-45 with Western blot analysis. Fig. 1 shows that higher levels of ER- $\alpha 36$ protein were detected in all four gastric cancer cell lines compared to ER-positive breast cancer MCF-7 cells. In addition, RT-PCR analysis confirmed ER- $\alpha 36$ mRNA was also highly expressed in all cell lines (Fig. 2). These results demonstrated that the novel variant of ER- $\alpha 36$ is highly expressed in established gastric cancer cells.

Previously, we demonstrated that ER- $\alpha 36$ is mainly expressed on the plasma membrane and in the cytoplasm of breast cancer cells (19). We decided to determine the localization of ER- $\alpha 36$ in gastric cancer cells. Indirect immunofluorescence assay with a specific anti-ER- $\alpha 36$ antibody revealed that ER- $\alpha 36$ is highly expressed outside of the cell nuclei; mainly on the plasma membrane and in the cytoplasm of the gastric cancer cells (Fig. 3).

ER-a36 expression is detected in human gastric adenocarcinoma tissues. To determine the expression patterns of ER- $\alpha 36$ in gastric adenocarcinoma tissues, the immunohistochemistry (IHC) assay was performed in specimens from 22 gastric cancer patients. The results showed that ER- $\alpha 36$ is expressed in 18 of $22(81.8 \%)$ specimens of primary gastric adenocarcinoma examined consistent with the results with established gastric cancer cell lines. We observed that ER- $\alpha 36$ exhibited cytoplasmic and membranous patterns in tumor specimens (Fig. 4).

We also performed RT-PCR analysis to assess expression levels of ER- $\alpha 36$ transcripts. ER- $\alpha 36$ transcripts were detected in tumor tissues $(\mathrm{T})$, adjacent non-malignant tissues (A) and corresponding normal tissues $(\mathrm{N})$ of all 22 gastric cancer patients (data not shown). Higher-levels of ER- $\alpha 36$ mRNA expression were detected in 17 of $22(77.27 \%)$ tumor specimens compared with the paired normal tissues $(\mathrm{p}<0.01)$. Fig. 5 shows RT-PCR results from four representative cases. In comparison with corresponding normal tissues, levels of ER- $\alpha 36$ mRNA expression were increased in tumor tissues of cases 1, 3 and 4 human gastric cancers (Fig. 5). 

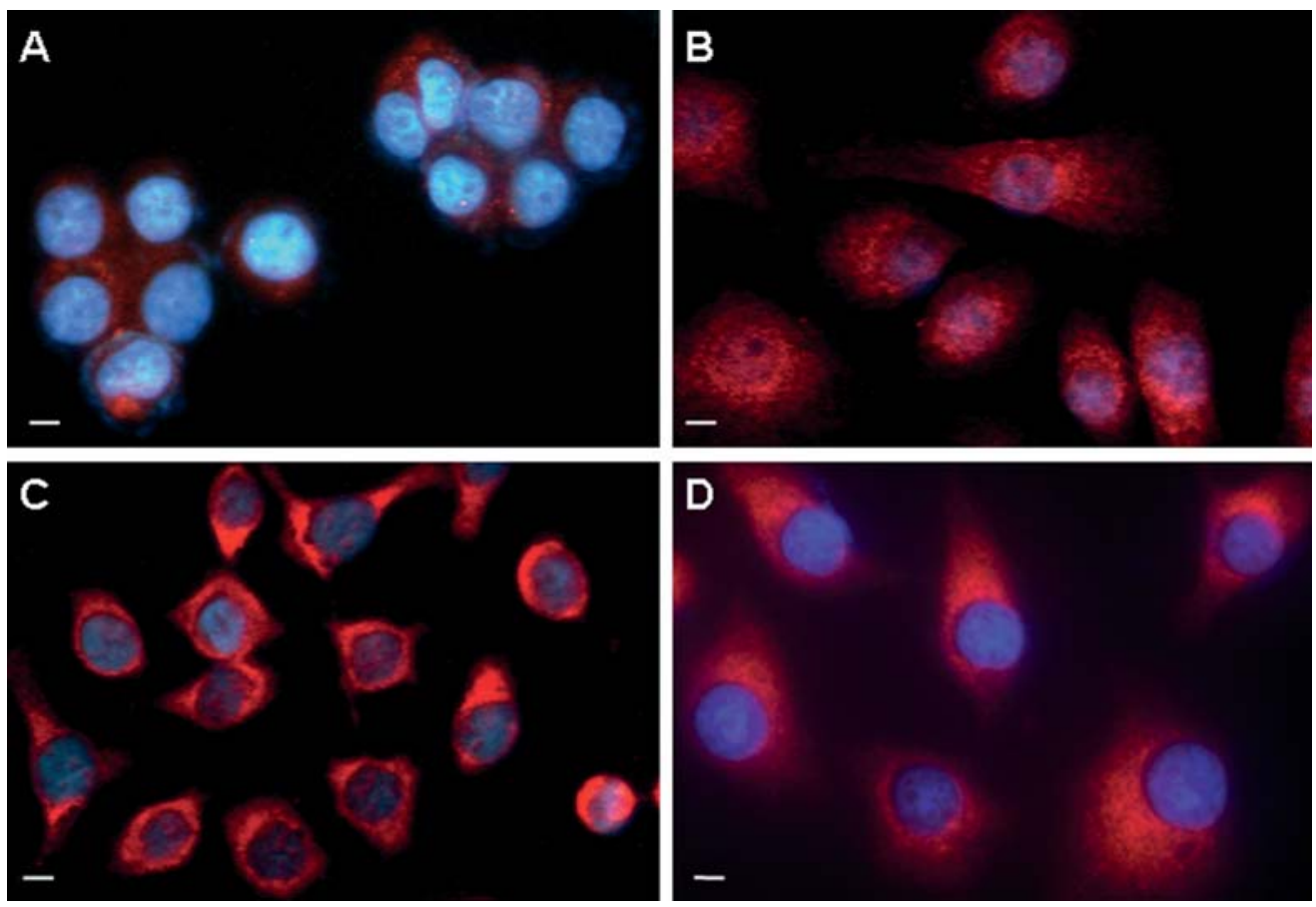

Figure 3. Indirect immunofluorescence analysis of ER- 336 expression in human gastric cancer cell lines. Merged images (original magnification, $\mathrm{x} 400)$ of SGC-7901 (A), MKN-45 (B), AGS (C) and BGC-823 (D) stained with an anti-ER-a36 antibody (red) and with Hoechst 33258 (blue). Scale bar, $10 \mu \mathrm{m}$.

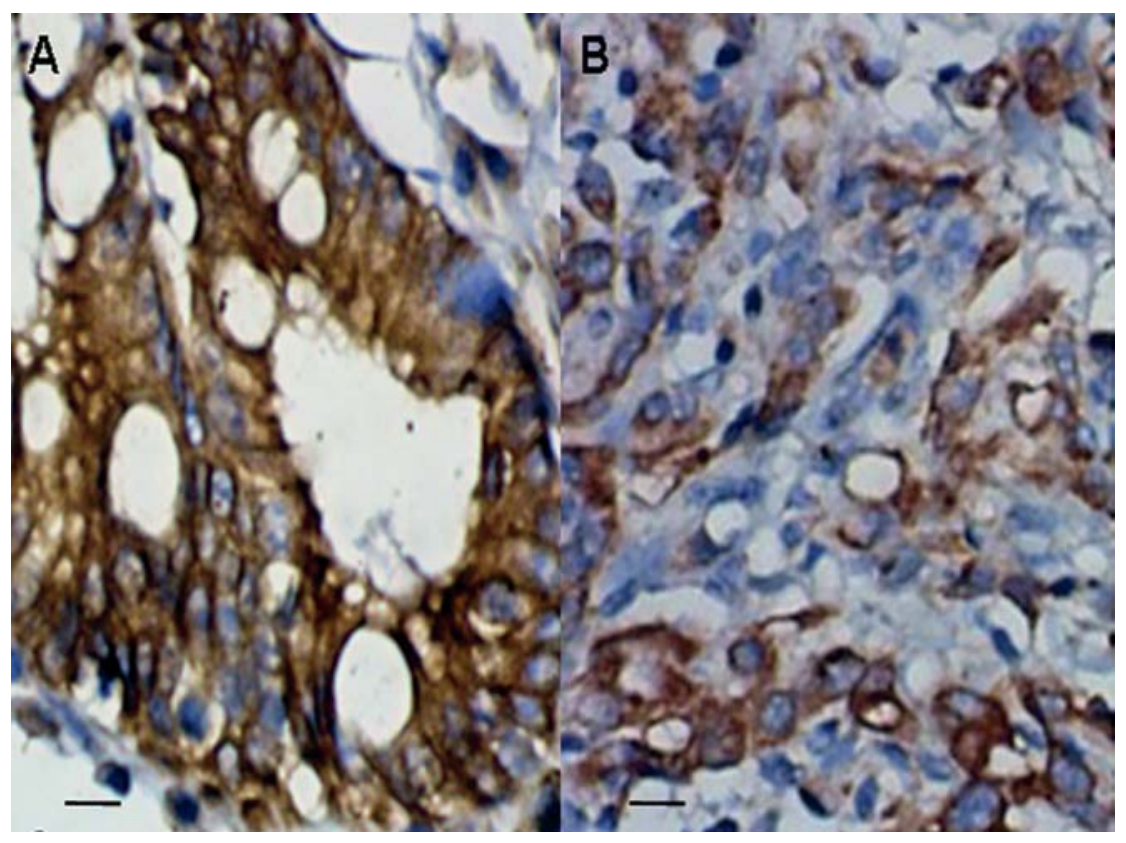

Figure 4. Immunohistochemical staining of ER- $\alpha 36$ in primary gastric adenocarcinoma, ER- $\alpha 36$ expression in high-differentiation (A) and low-differentiation (B) gastric adenocarcinoma (magnification, $\mathrm{x} 200$ ). Scale bar, $20 \mu \mathrm{m}$.

ER- $\alpha 36$ expression is correlated with lymph node metastasis. We also assessed whether ER- $\alpha 36$ expression correlated with the clinicopathological properties of gastric adenocarcinoma. Table I shows that ER- $\alpha 36$ expression was not associated with gender, age, tumor size, histological differentiation and tumor stage. However, ER- $\alpha 36$ expression was significantly associated with lymph node metastasis $(\mathrm{P}=0.0372)$.

\section{Discussion}

Previous studies have reported conflicting expression results for the classical ER- $\alpha$ (ER- $\alpha 66)$ in gastric cancer (20-25). Using the immunohistochemical method, gastric tumor tissues were often considered as ER-negative or low-expression tissues $(2-28 \%$ of the tumors) $(20,21)$. It was reported that in 


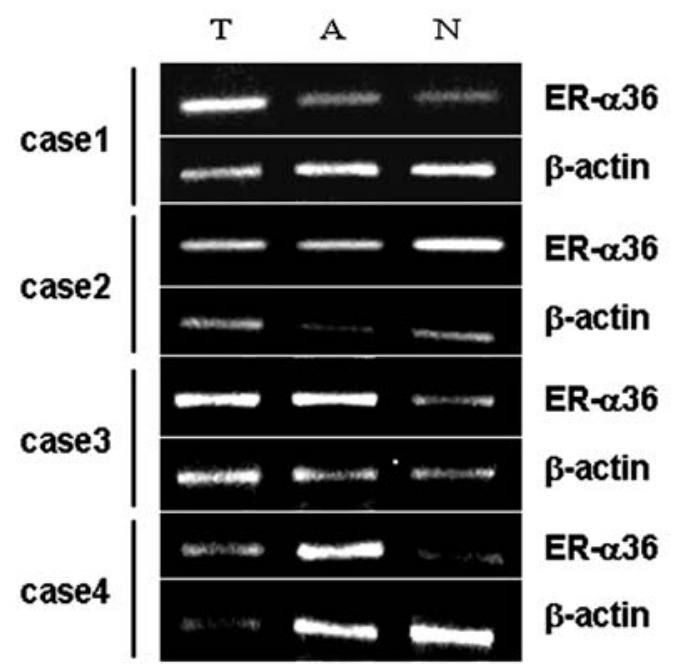

Figure 5. RT-PCR analysis of ER- $\alpha 36$ mRNA level in specimens of gastric adenocarcinoma. ER- $\alpha 36$ expression in tumor tissues (T), adjacent nonmalignant tissues (A) and corresponding normal tissues (N) was assessed with RT-PCR method.

gastric cancer, ER- $\alpha 66$ expression showed no difference between cancerous and normal tissues and no correlation with tumor grade (22). However, in other studies, it was found that ER- $\alpha 66$ expression in gastric cancer correlated with a worse prognosis (23) and more widespread lymph node metastasis $(24,25)$. Thus, the expression and possible function of ER- $\alpha 66$ in development of human gastric cancer is controversial.

In this study, we found that ER- $\alpha 36$ is highly expressed in established gastric cancer cell lines including SGC-7901, AGS, BGC-923, and MKN-45. Using indirect immunofluorescence staining, we demonstrated that ER- $\alpha 36$ was mainly expressed on the plasma membrane and in the cytoplasm of gastric cancer cells. Both ER- $\alpha 36$ mRNA and protein were also detected in most specimens from human gastric cancer patients; exhibiting higher levels of expression compared to their matched normal tissues. Our results thus for the first time indicated that the ER- $\alpha$ variant ER- $\alpha 36$ is highly expressed in human gastric adenocarcinoma tissues and suggested that the non-genomic estrogen signaling mediated by ER- $\alpha 36$ may be involved in gastric carcinogenesis.

We also found that ER- $\alpha 36$ protein was mainly expressed on the plasma membrane and in the cytoplasm of gastric cancer specimens. It is worth noting that a weak cytoplasmic pattern of ER- $\alpha 66$ expression was frequently observed in ER- $\alpha 36$-expressing breast cancer tissues while mainly in the cell nuclei in ER- $\alpha 36$-negative breast cancer cells (19), suggesting that ER- $\alpha 36$ expression may influence ER- $\alpha 66$ cellular localization. Previously, it was reported that ER- $\alpha 66$ expression was observed predominantly in the cytoplasm of gastric cancer cells (18). Thus, it is possible that these cells might also express ER- $\alpha 36$.

We further found that high levels of ER- $\alpha 36$ expression significantly correlated with lymph node metastasis in gastric cancer. Lymph node metastasis is one of the most important prognostic factors in gastric cancer. Thus, enhanced ER- $\alpha 36$
Table I. Relationship between expression level of ER- $\alpha 36$ mRNA and clinicopathological characteristics.

\begin{tabular}{|c|c|c|c|}
\hline Factors & $\begin{array}{c}\text { Low } \\
\text { expression }\end{array}$ & $\begin{array}{c}\text { High } \\
\text { expression }\end{array}$ & P-value \\
\hline Age & & & 0.3649 \\
\hline$\leq 60$ years & 2 & 9 & \\
\hline$>60$ years & 3 & 8 & \\
\hline Gender & & & 0.391 \\
\hline Men & 3 & 10 & \\
\hline Female & 2 & 7 & \\
\hline Tumor size & & & 0.3628 \\
\hline$\leq 5 \mathrm{~cm}$ & 2 & 5 & \\
\hline$>5 \mathrm{~cm}$ & 3 & 12 & \\
\hline Histological differentiation & & & 0.4416 \\
\hline High differentiation & 1 & 2 & \\
\hline Low differentiation & 4 & 15 & \\
\hline T stage & & & 0.4519 \\
\hline $\mathrm{T} 2-3$ & 4 & 13 & \\
\hline $\mathrm{T} 4$ & 1 & 4 & \\
\hline $\mathrm{N}$ stage & & & 0.0372 \\
\hline No & 4 & 4 & \\
\hline $\mathrm{N} 1-3$ & 1 & 13 & \\
\hline
\end{tabular}

expression in gastric adenocarcinoma may be involved in increased metastasis, suggesting that ER- $\alpha 36$ expression can be used as a predictive marker for metastasis.

\section{Acknowledgements}

This work was supported by National Natural Science Foundation of China grant 30870981 (L.J. Liu); Huibei Health Foundation grant NX200727 (L.J. Liu); Wuhan Young Chenguang Foundation grant 20045006071-7 (H. Deng); and Hubei Natural Science Foundation grant 2006AB191 (H. Deng). This work was also supported by NIH grant DK070016 (Z.Y. Wang).

\section{References}

1. Nilsson S, Makela S, Treuter E, Tujague M, Thomsen J, Andersson G, Enmark E, Pettersson K, Warner M and Gustafsson JA: Mechanisms of estrogen action. Physiol Rev 81: $1535-1565,2001$

2. Greene GL, Gilna P, Waterfield M, Baker A, Hort Y and Shine J: Sequence and expression of human estrogen receptor complementary DNA. Science 231: 1150-1154, 1986.

3. Greene GL and Press MF: Structure and dynamics of the estrogen receptor. J Steroid Biochem 24: 1-7, 1986.

4. Kuiper GG, Enmark E, Pelto-Huikko M, Nilsson S and Gustafsson JA: Cloning of a novel receptor expressed in rat prostate and ovary. Proc Natl Acad Sci USA 93: 5925-5930, 1996.

5. Zhang WH, Andersson S, Cheng G, Simpson ER, Warner M and Gustafsson JA: Update on estrogen signaling. FEBS Lett 546: 17-24, 2003. 
6. Kong EH, Pike AC and Hubbard RE: Structure and mechanism of the oestrogen receptor. Biochem Soc Trans 31: 56-59, 2003

7. Segars JH and Driggers PH: Estrogen action and cytoplasmic signaling cascades. Part I: membrane-associated signaling complexes. Trends Endocrinol Metab 13: 349-354, 2002.

8. Wang ZY, Zhang XT, Shen P, Loggie BW, Chang YC and Deuel TF: Identification, cloning, and expression of human estrogenreceptor- $\alpha 36$, a novel variant of human estrogen receptor- $\alpha 66$. Biochem Biophys Res Commun 336: 1023-1027, 2005.

9. Wang ZY, Zhang XT, Shen P, Loggie BW, Chang YC and Deuel TF: A variant of estrogen receptor- $\alpha, \mathrm{hER}-\alpha 36$ : transduction of estrogen- $\alpha$ and antiestrogen-dependent membraneinitiated mitogenic signaling. Proc Natl Acad Sci USA 103 9063-9068, 2006.

10. Zou Y, Ding L, Coleman M and Wang Z: Estrogen receptoralpha (ER-alpha) suppresses expression of its variant ER-alpha36. FEBS Lett 583: 1368-1374, 2009.

11. La Vecchia C, D'Avanzo B, Franceschi S, Negri E, Parazzini F and Decarli A: Menstrual and reproductive factors and gastriccancer risk in women. Int J Cancer 59: 761-764, 1994.

12. Brenner H, Rothenbacher D and Arndt V: Epidemiology of stomach cancer. Methods Mol Biol 472: 467-477, 2009.

13. Palli D, Cipriani F, Decarli A, Galli M, Saieva C, Fraumeni JF Jr, Blot WJ and Buiatti E: Reproductive history and gastric cancer among post-menopausal women. Int J Cancer 56: 812-815, 1994.

14. Tokunaga A, Nishi K, Matsukura N, Tanaka N, Onda M, Shirota A, Asano G and Hayashi K: Estrogen and progesterone receptors in gastric cancer. Cancer 57: 1376-1379, 1986.

15. Matsui M, Kojima O, Uehara Y and Takahashi T: Characterization of estrogen receptor in human gastric cancer. Cancer 68: 305-308, 1991.

16. Singh S, Poulsom R, Wright NA, Sheppard MC and Langman MJ: Differential expression of oestrogen receptor and oestrogen inducible genes in gastric mucosa and cancer. Gut 40: 516-520, 1997.
17. Furukawa $H$, Iwanaga $T$, Koyama $H$ and Taniguchi $H$ : Effect of sex hormones on carcinogenesis in the stomachs of rats. Cancer Res 42: 5181-5182, 1982 .

18. Nishi K, Tokunaga A, Shimizu Y, Yoshiyuki T, Wada M, Matsukura N, Tanaka N, Onda M and Asano G: Immunohistochemical study of intracellular estradiol in human gastric cancer. Cancer 59: 1328-1332, 1987.

19. Lee LM-J, Cao J, Chen P, Gatalica Z and Wang Z-Y: ER- $\alpha 36$, a novel variant of $E R-\alpha$, is expressed in ER- $\alpha$ positive and negative human breast carcinomas. Anticancer Res 28: 479-484, 2008.

20. Takano N, Iizuka N, Hazama S, Yoshino S, Tangoku A and Oka M: Expression of estrogen receptor-alpha and -beta mRNAs in human gastric cancer. Cancer Lett 176: 129-135, 2002.

21. Wang M, Pan JY, Song GR, Chen HB, An LJ and Qu SX: Altered expression of estrogen receptor alpha and beta in advanced gastric adenocarcinoma: Correlation with prothymosin alpha and clinicopathological parameters. Eur J Surg Oncol 133: 195-201, 2007.

22. Cui G, Yuan A Qvigstad G and Waldum HL: Estrogens receptors are not expressed in esophagogastric carcinomas that come from a high incidence area of China. Hepatogastroenterology 48: 594-595, 2001.

23. Harrison JD, Jones JA, Ellis IO and Morris DL: Oestrogen receptor D5 antibody is an independent negative prognostic factor in gastric cancer. Br J Surg 78: 334-336, 1991.

24. Zhao XH, Gu SZ, Liu SX and Pan BR: Expression of estrogen receptor and estrogen receptor messenger RNA in gastric carcinoma tissues. World J Gastroenterol 9: 665-669, 2003.

25. Matsui M, Kojima O, Kawakami S, Uehara Y and Takahashi T: The prognosis of patients with gastric cancer possessing sex hormone receptors. Surg Today 22: 421-425, 1992. 